\title{
INVENTARISASI EKHINODERMATA DI EKOSISTEM TERUMBU KARANG PERAIRAN SELAT LEMBEH
}

\author{
Doni Nurdiansah, Supono \\ Konservasi Biota Laut, Pusat Penelitian Oseanografi, LIPI, \\ Jakarta, Indonesia \\ E-mail :dnurdiansah@gmail.com
}

Received March 2020, Accepted August 2020

\begin{abstract}
ABSTRAK
Perairan Selat Lembeh (Sulawesi Utara) merupakan salah satu perairan di Indonesia yang memiliki ekosistem yang unik dan dikenal secara internasional terutama untuk wisata selam. Kombinasi habitat lamun di beberapa titik ekosistem terumbu karang dan rataan substrat yang merupakan campuran pasir, lumpur dan patahan karang memungkinkan banyak biota laut yang tinggal dan mencari makanan di perairan ini, termasuk kelompok ekhinodermata. Tujuan penelitian ini adalah untuk mengetahui distribusi ekhinodermata di ekosistem terumbu karang berdasarkan tingkat kedalaman.Pengambilan data dilakukan pada bulan Maret hingga Oktober 2013 dengan menggunakan metode transek sabuk (belt transect). Selama pengamatan tercatat 443 individu yang tergolong dalam 19 jenis ekhinodermata. Jumlah jenis terdiri dari 7 jenis kelompok bintang laut (Asteroidea), 4 jenis kelompok bulu babi (Echinoidea), 5 jenis kelompok bintang mengular (Ophiuroidea), 2 jenis kelompok timun laut (Holothuroidea) dan 1 jenis kelompok lili laut (Crinoidea). Tingkat keanekaragaman $\left(H^{\prime}=1,83\right)$, kekayaan jenis $(D=2,53)$ dan kemerataan $(\mathrm{J}=0,95)$ di perairan ini tergolong tinggi dibandingkan perairan lain di Sulawesi Utara. Tingkat kedalaman yang memiliki jumlah jenis ekhinodermata paling tinggi adalah kedalaman $6 \mathrm{~m}$ hingga $9 \mathrm{~m}$.
\end{abstract}

Kata Kunci : Ekhinodermata, Keanekaragaman, Perairan Selat Lembeh

\section{ABSTRACT}

\begin{abstract}
INVENTORY OF ECHINODERM IN CORAL REEF ECOSYSTEM LEMBEH STRAIT WATERS. Lembeh Strait waters (North Sulawesi) is one of areas in Indonesia demonstrates marine ecosystem and is globally known, particularly for diving tourism. Combination of seagrass beds, coral reefs, and bottom substrates consisting of black sand, mud and rubbles provides habitat and feeding ground for wide range of marine biota, including echinoderm. The present study aims to identify echinoderm distribution in related to water depth. Data collection was conducted from March to October 2013 applying belt transect method. A total of 443 individual of echinoderms belong to 19 species were recorded. Of these,
\end{abstract}


seven species were Asteroidea, four species Echinoidea, five species were Ophiuroidea, two species were Holothuroidea, and one species were Crinoidea. Diversity $\left(H^{\prime}=1.83\right)$, richness $(D=2.53)$ and Evennes Index $(J=0.95)$ were relatively high in comparison to other areas in North Sulawesi. According to this study, the highest species richness was found from six to nine metres.

Keywords : Echinoderm, Diversity, Lembeh Strait Waters

\section{PENDAHULUAN}

Perairan Selat Lembeh merupakan perairan yang memiliki habitat unik dan dikenal secara internasional terutama untuk wisata selam. Kombinasi habitat lamun di beberapa titik, ekosistem terumbu karang dan rataan substrat yang merupakan campuran pasir, lumpur dan patahan karang memungkinkan banyak biota laut yang tinggal dan mencari makan di perairan ini. Arus yang membawa massa air laut dari Sulawesi (sebelah utara) dan laut Maluku (sebelah selatan) menjadikan perairan ini habitat bagi beberapa biota unik. Selain itu, perairan Selat Lembeh menempati geoposisi strategis dengan banyaknya aktivitas perekonomian, perikanan, lalu lintas penyeberangan antarpulau dan wisata bawah air. Menurut de Vantier dan Turak (2004), selat ini merupakan jalur pelayaran yang sibuk, tetapi juga telah secara luas dianggap sebagai lokasi muck dive yang sangat penting selama lebih dari lima belas tahun. Banyaknya aktivitas menyelam di sekitar perairan Selat Lembeh ini meningkatkan wisatawan selama enam tahun terakhir dengan dibangunnya resort baru dan pusat penyelaman setiap tahunnya (De Brauwer et al., 2017).

Fauna ekhinodermata merupakan penyusun komunitas yang memiliki proporsi kehadiran relatif tinggi di ekosistem terumbu karang. Estradivari et al. (2007) menyatakan bahwa dalam penelitian proporsi kelimpahan makrobenthos di perairan, ekhinodermata menempati urutan ketiga, yaitu mencapai 0,68\%. Ekhinodermata banyak dilaporkan berasosiasi dengan terumbu karang baik yang bersifat parasit, mutual maupun komensal. Asosiasi yang bersifat parasit ditunjukkan oleh bintang laut Acanthaster plancii yang merupakan pemakan polip karang yang dalam kepadatan dan periode tertentu akan menyebabkan kematian karang. Bintang laut ini memakan polip atau bagian lunak dari karang hingga menyebabkan karang berubah warna menjadi putih. Jenis bintang laut ini mampu hidup dari kedalaman 0 hingga $30 \mathrm{~m}$ (Baird et al., 2013; Plass-Johnson et al., 2015).

Penelitian mengenai preferensi jenis karang yang dimakan menunjukkan bahwa karang jenis Acropora paling banyak diminati oleh bintang laut $A$. plancii. Lima belas jenis karang Acropora, 6 jenis karang Porites dan 4 jenis karang Pocillopora dilaporkan merupakan makanan bintang laut $A$. plancii (Al Hakim, 1983). Bintang laut $A$. plancii dewasa lebih menyukai jenis karang meja untuk menghindari predator dan menghindari arus. Satu individu dewasa $A$. planci dilaporkan mampu memakan 5-6 $\mathrm{m}^{2}$ tutupan karang hidup dalam kurun waktu satu tahun 
(Birkeland, 1989). Asosiasi yang memiliki dampak negatif juga terjadi di antara bulu babi dan tutupan alga di ekosistem terumbu karang. Paine \& Vadas (1969) melaporkan bahwa agregasi (sifat hidup berkelompok) bulu babi dari marga Strongulocentrotus mengurangi tutupan alga di perairan.

Asosiasi positif (mutual) antara fauna ekhinodermata dan karang ditunjukkan oleh kelompok timun laut. Kehadiran beberapa jenis timun laut dilaporkan memiliki hubungan mutualis terhadap pertumbuhan karang secara tidak langsung. Timun laut jenis Pearsonothuria graeffei sering dijumpai memakan detritus yang menempel pada polip karang. Hal ini akan menguntungkan karang dalam meningkatkan intensitas penangkapan cahaya sehingga karang bisa tumbuh lebih baik. Timun laut juga dilaporkan berperan dalam siklus karbon yang terdapat di substrat dasar perairan. Timun laut dilaporkan memakan detritus dan sedimen dasar perairan. Timun laut jenis Holothuria atra mengkonsumsi $10 \%-40 \%$ bakteri karbon yang ada di sedimen dan berperan dalam siklus karbon di ekosistem terumbu karang (Moriarty et al., 1985). Peran kehadiran kelompok lili laut dan bintang mengular di ekosistem terumbu karang belum banyak dilaporkan oleh peneliti hingga saat ini. Aziz (1995) menyampaikan bahwa bintang mengular merupakan pakan bagi ikan demersal.

Tingginya tekanan aktivitas manusia ditambah dengan pengaruh perubahan iklim global membawa ancaman tersendiri terhadap keberadaan ekosistem terumbu karang dan biota yang berasosiasi didalamnya,salah satunya ekhinodermata. Oleh karena itu, penelitian ini bertujuan untuk mengetahui distribusi ekhinodermata di ekosistem terumbu karang berdasarkan tingkat kedalaman. Informasi mengenai inventarisasi ekhinodermata di ekosistem terumbu karang perairan Selat Lembeh penting untuk mengetahui status keanekaragaman dan peran fauna tersebut terhadap ekosistem terumbu karang. Dengan adanya gambaran keanekaragaman ekhinodermata dan jenis yang bersifat parasit terhadap terumbu karang, maka diharapkan bisa dijadikan dasar untuk pengelolaan ekosistem di masa mendatang.

\section{MATERI DAN METODE}

\section{Waktu dan Lokasi Penelitian}

Penelitian inventarisasi fauna ekhinodermata dilakukan di 16 lokasi di perairan Selat lembeh dari bulan Maret sampai dengan bulan Oktober 2013.

\section{Prosedur Pengambilan Data}

Pengambilan data ekhinodermata dilakukan dengan menggunakan metode transek sabuk (belt transect) dan koleksi bebas (Eleftheriou \& Mcintyre, 2005). Metode transek sabuk dilakukan dengan menggunakan tali sepanjang 10 meter diletakkan sejajar garis pantai dengan lima tingkat kedalaman air yaitu 3, 6, 9, 12 dan 15 m. Ekhinodermata yang ditemukan 
dalam jarak satu meter di kedua sisi tali transek dicatat dan beberapa jenis diambil untuk disimpan di laboratorium Loka Konservasi Biota Laut LIPI Bitung, Sulawesi Utara.

Sampel diawetkan dengan menggunakan alkohol 70\%. Koleksi bebas dilakukan di luar garis transek untuk melengkapi data kehadiran ekhinodermata.

Identifikasi ekhinodermata dilakukan dengan merujuk pada Clark and Rowe (1971). Struktur komunitas ekhinodermata akan dianalisa dengan menggunakan analisis indeks keanekaragaman, kekayaan dan kemerataan jenis dilakukan dengan menggunakan software program Primer 5 (Mcaleece et al., 1997). Sedangkan persamaan kuantitatif komposisi dan jumlah jenis kumulatif ekhinodermata antar stasiun penelitian dihitung dengan menggunakan indeks persamaan Sorensen dengan mengaplikasikan software BioDiversity Pro (Brower dan Zar 1977).

Tabel 1. Nama stasiun dan titik koordinat lokasi penelitian

\begin{tabular}{|c|c|c|c|c|}
\hline \multirow{2}{*}{ No } & \multirow{2}{*}{ Nama Stasiun } & \multirow{2}{*}{ Lokasi } & \multicolumn{2}{|c|}{ Titik Koordinat } \\
\hline & & & Utara & Selatan \\
\hline 1 & Stasiun 1 & Tanjung Paudean & $1.40121^{\circ}$ & $125.1653^{\circ}$ \\
\hline 2 & Stasiun 2 & Tanjung Lampu & $1.43277^{\circ}$ & $125.1875^{\circ}$ \\
\hline 3 & Stasiun 3 & Papusungan & $1.43564^{\circ}$ & $125.2096^{\circ}$ \\
\hline 4 & Stasiun 4 & Mawali & $1.44042^{\circ}$ & $125.226^{\circ}$ \\
\hline 5 & Stasiun 5 & Tanjung Kusu-kusu & $1.45195^{\circ}$ & $125.2382^{\circ}$ \\
\hline 6 & Stasiun 6 & Kareko & $1.47009^{\circ}$ & $125.245^{\circ}$ \\
\hline 7 & Stasiun 7 & Binuang & $1.48715^{\circ}$ & $125.2563^{\circ}$ \\
\hline 8 & Stasiun 8 & Tanjung Nusu & $1.50975^{\circ}$ & $125.2694^{\circ}$ \\
\hline 9 & Stasiun 9 & Batu Angus & $1.50381^{\circ}$ & $125.2476^{\circ}$ \\
\hline 10 & Stasiun 10 & Kambahu & $1.48969^{\circ}$ & $125.2407^{\circ}$ \\
\hline 11 & Stasiun 11 & Pantai LIPI & $1.45973^{\circ}$ & $125.2271^{\circ}$ \\
\hline 12 & Stasiun 12 & Tanjung Nanas & $1.46238^{\circ}$ & $125.2283^{\circ}$ \\
\hline 13 & Stasiun 13 & Aerprang & $1.46997^{\circ}$ & $125.2354^{\circ}$ \\
\hline 14 & Stasiun 14 & Tandurusa & $1.4572^{\circ}$ & $125.2193^{\circ} \circ$ \\
\hline 15 & Stasiun 15 & Naemundung (Kb. Binatang) & $1.45205^{\circ}$ & 125.2119 은 \\
\hline 16 & Stasiun 16 & Rarandam & $1.44652^{\circ}$ & $125.2357^{\circ}$ \\
\hline
\end{tabular}




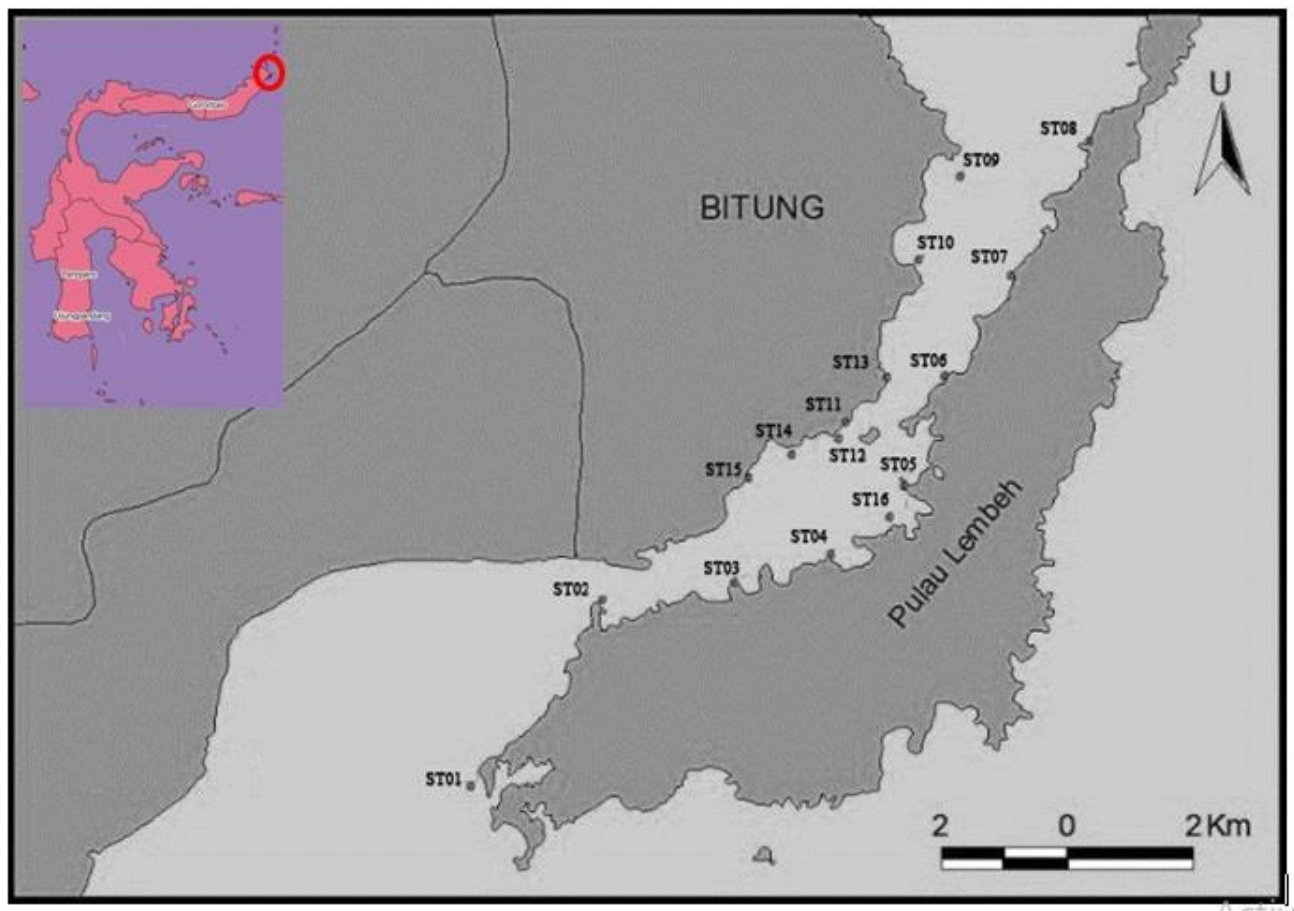

Gambar 1. Sebaran lokasi penelitian di perairan Selat Lembeh

\section{HASIL DAN PEMBAHASAN}

Pada penelitian ini, dari 16 lokasi penelitian tercatat 443 individu yang tergolong dalam 19 jenis ekhinodermata. Jumlah jenis terdiri dari 7 jenis kelompok bintang laut (Asteroidea), 4 jenis kelompok bulu babi (Echinoidea), 5 jenis kelompok bintang mengular (Ophiuroidea), 2 jenis kelompok timun laut (Holothuroidea) dan 1 jenis kelompok lili laut (Crinoidea). Jumlah individu ekhinodermata yang tercatat berasal dari lima tingkat kedalaman. Stasiun Tanjung Paudean (ST 01) dan stasiun Kareko (ST 06) memiliki jumlah jenis ekhinodermata yang paling tinggi yaitu 10 jenis. Sedangkan stasiun Aerprang (ST 13) memiliki jumlah jenis ekhinodermata paling rendah yaitu 1 jenis. Jenis-jenis ekhinodermata yang ditemukan di perairan Selat Lembeh disajikan pada Tabel 2.

Tabel 2. Kehadiran jenis ekhinodermata di tiap stasiun

\begin{tabular}{|c|c|c|c|c|c|c|c|c|c|c|c|c|c|c|c|c|c|}
\hline \multirow{2}{*}{ No } & \multirow{2}{*}{ Spesies } & \multicolumn{16}{|c|}{ Stasiun } \\
\hline & & 1 & 2 & 3 & 4 & 5 & 6 & 7 & 8 & 9 & 10 & 11 & 12 & 13 & 14 & 15 & 16 \\
\hline & Asteroidea & & & & & & & & & & & & & & & & \\
\hline 1 & $\begin{array}{l}\text { Celerina } \\
\text { heffernani }\end{array}$ & - & + & - & - & - & - & - & - & - & - & - & - & - & - & - & - \\
\hline 2 & $\begin{array}{l}\text { Choriaster } \\
\text { granulatus }\end{array}$ & + & - & - & - & - & - & - & - & - & - & - & - & - & - & - & - \\
\hline 3 & $\begin{array}{l}\text { Culcita } \\
\text { novaeguineae }\end{array}$ & + & - & - & + & - & - & + & - & - & + & - & + & - & - & + & - \\
\hline 4 & Fromia monilis & - & - & - & - & - & + & - & - & + & - & - & - & - & - & - & - \\
\hline
\end{tabular}




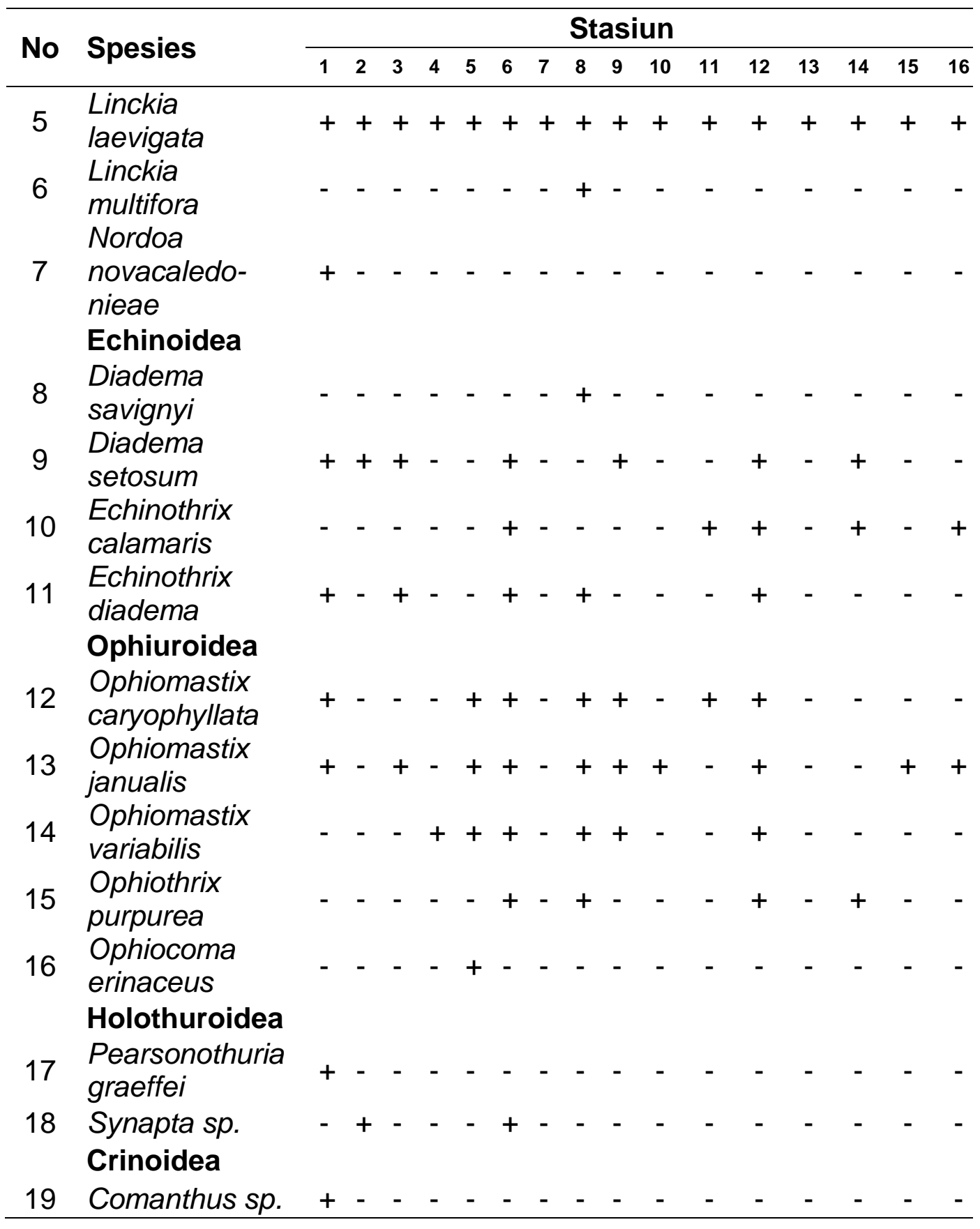

Hasil analisa data, diperoleh nilai indeks keanekaagaman jenis $(\mathrm{H})$ tertinggi pada stasiun Kareko (ST 06) sebesar 1,83 dan terkecil di stasiun Aerprang (ST 13) sebesar 0 . Nilai indeks kemerataan jenis (J) tertinggi diperoleh di stasiun Kambahu (ST 10) dan stasiun Naemundung (ST 15) sebesar 0,95 dan terkecil di stasiun Aerprang (ST 13) sebesar 0, sementara nilai indeks kekayaan jenis (D) tertinggi ditemukan di stasiun Kareko (ST 06) sebesar 2,53 dan terendah di stasiun Aerprang (ST 13) sebesar 0 . Hasil analisa tersebut untuk di tiap stasiun disajikan pada Tabel 3. 
Tabel 3. Indek keanekaragaman, kekayaan dan kemerataan jenis

\begin{tabular}{|c|c|c|c|c|c|c|c|c|c|c|c|c|c|c|c|c|}
\hline Indek & 1 & 2 & 3 & 4 & 5 & 6 & 7 & 8 & 9 & 10 & 11 & 12 & 13 & 14 & 15 & 16 \\
\hline $\begin{array}{l}\text { Indek } \\
\text { keka- } \\
\text { yaan } \\
\text { jenis }\end{array}$ & 2.2 & 0.9 & 0.8 & 0.7 & 1.1 & 2.5 & 0.4 & 1.6 & 1.5 & 1.4 & 0.9 & 1.9 & 0 & 1.1 & 1.4 & 0.9 \\
\hline $\begin{array}{l}\text { Indek } \\
\text { keme- } \\
\text { rataan }\end{array}$ & 0.7 & 0.8 & 0.6 & 0.7 & 0.8 & 0.8 & 0.5 & 0.8 & 0.8 & 1 & 0.8 & 0.7 & 0 & 0.6 & 1 & 0.8 \\
\hline $\begin{array}{l}\text { Indek } \\
\text { Kea- } \\
\text { neka } \\
\text { Raga- } \\
\text { man }\end{array}$ & 1.6 & 1 & 0.8 & 0.7 & 1.3 & 1.8 & 0.3 & 1.7 & 1.4 & 1 & 0.9 & 1.5 & 0 & 0.9 & 1 & 0.9 \\
\hline
\end{tabular}

Indeks persamaan jenis digunakan untuk mengetahui tingkat persamaan komposisi jenis ekhinodermata secara keseluruhan pada lokasi yang berbeda. Hasil analisa persamaan komposisi jenis ekhinodermata di 16 lokasi disajikan pada Gambar 2. Tingkat kemiripan diatas 80\% ditemukan pada antara stasiun 10 dan 15, 4 dan 7, 12 dan 6 . Stasiun 10 dan 15 memiliki tingkat kemiripan 100\% karena ditemukan 3 jenis ekhinodermata yang sama di kedua lokasi. Sedangkan stasiun lainnya memiliki tingkat kemiripan dibawah $70 \%$.

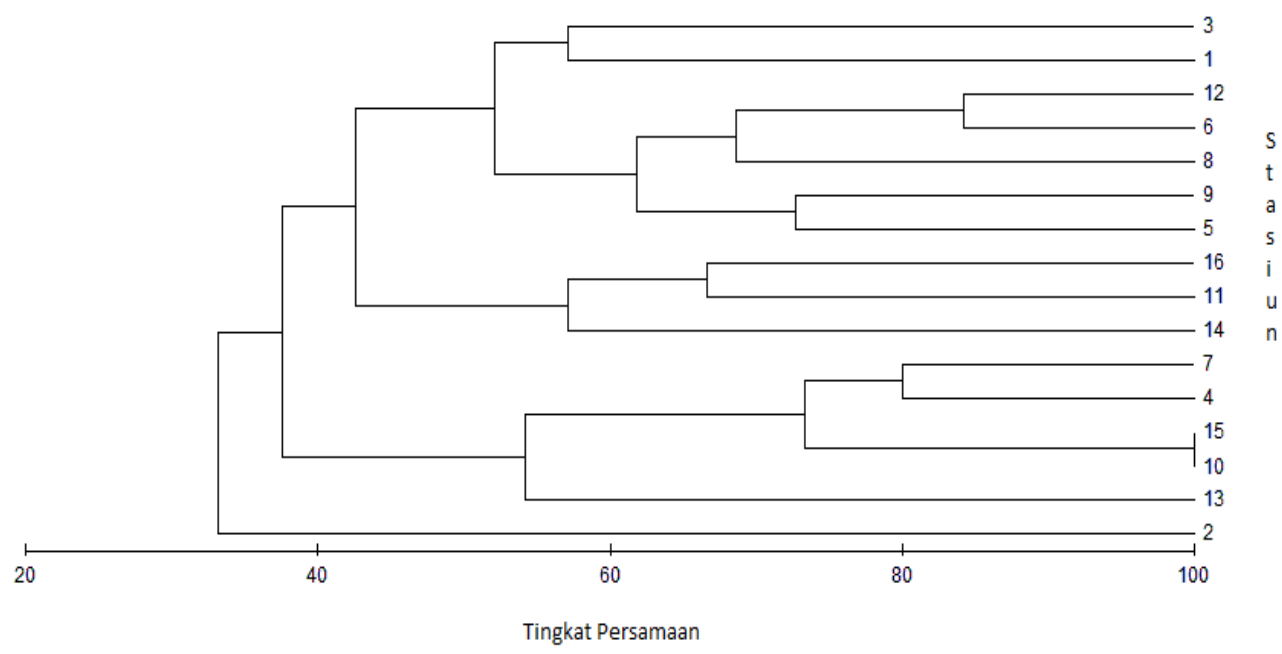

Gambar 2. Dendogram hasil analisis persamaan per stasiun

\section{Distribusi berdasarkan Kedalaman}

Distribusi ekhinodermata berdasarkan tingkat kedalaman menunjukkan bahwa tingkat kedalaman yang memiliki kekayaan jenis tertinggi pada penelitian ini adalah $6 \mathrm{~m}, 9 \mathrm{~m}$ dan $12 \mathrm{~m}$ yaitu 11 jenis ekhinodermata. Sedangkan pada kedalaman $3 \mathrm{~m}$ dan $15 \mathrm{~m}$ hanya ditemukan 8 jenis ekhinodermata (Gambar 3). Jika dibandingkan dengan jumlah individu di setiap kedalaman, biomassa ekhinodermata tertinggi 
diperoleh pada kedalaman $3 \mathrm{~m}$ dengan 165 individu. Hasil tabulasi data menunjukkan bahwa meskipun pada kedalaman $3 \mathrm{~m}$ memiliki jumlah individu paling besar namun tingkat dominansi jenis pada kedalaman ini sangat besar jika dibandingkan dengan jumlah jenis yang ditemukan pada kedalaman yang sama. Pada penelitian ini, kedalaman $3 \mathrm{~m}$ di dominasi oleh jenis bulu babi Diadema setosum. Jenis ini merupakan jenis bulu babi umum yang bisa ditemukan hampir di semua jenis habitat mulai dari padang lamun, terumbu karang maupun daerah rataan campuran pasir dan patahan karang yang telah ditumbuhi oleh alga. Jenis bulu babi ini mampu hidup di kedalaman $0 \mathrm{~m}$ hingga $70 \mathrm{~m}$ (The Nature Conservancy, 2004).

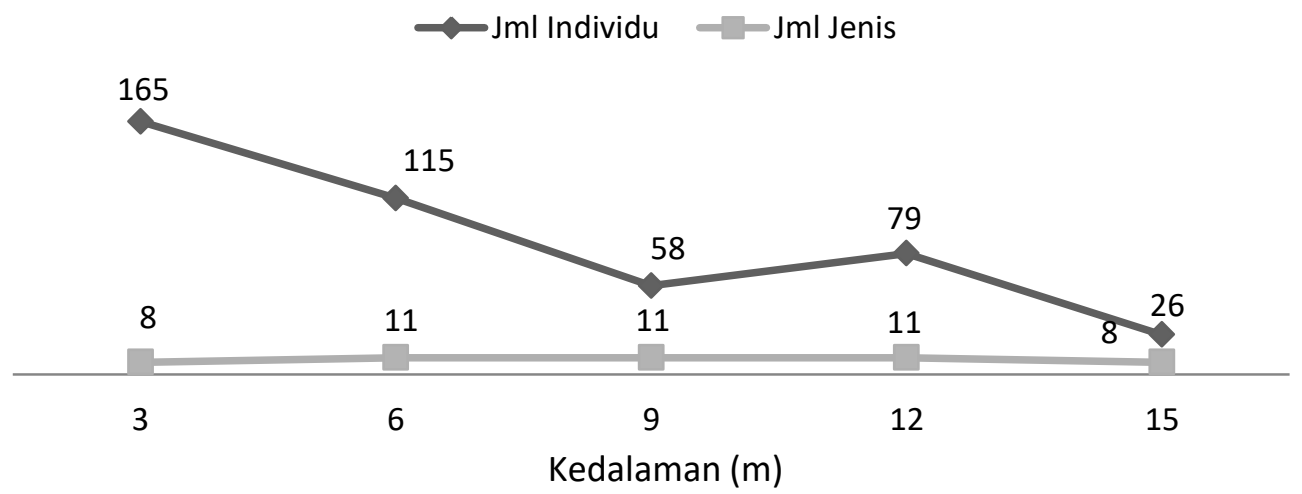

Gambar 3. Jumlah jenis dan individu berdasarkan kedalaman di 16 stasiun penelitian.

\section{Sebaran Jenis dan Jumlah Individu}

Sedangkan jika dilihat sebaran jenis dan jumlah individu berdasarkan stasiun penelitian menunjukkan bahwa stasiun 1 dan 10 merupakan stasiun yang memiliki kekayaan jenis paling tinggi yaitu 10 jenis dengan jumlah individu 56 individu (stasiun 1) dan 36 individu (stasiun 6). Sedangkan stasiun yang paling memiliki kehadiran jenis paling rendah adalah stasiun 13 dengan hanya 1 jenis dan 10 individu (Gambar 4).

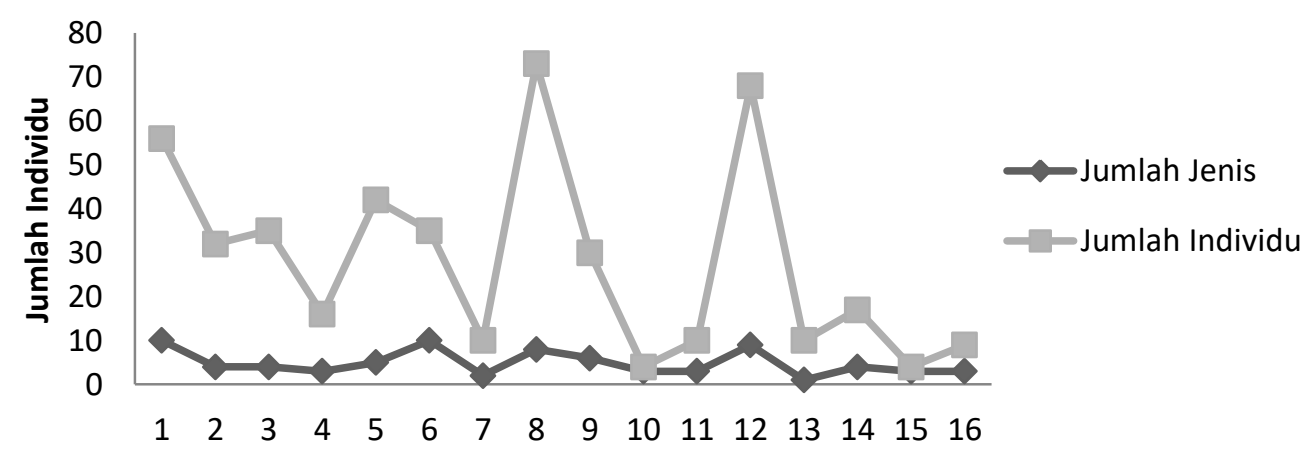

\section{Stasiun}

Gambar 4. Jumlah jenis dan individu berdasarkan stasiun penelitian 
Jumlah jenis ekhinodermata yang diperoleh dari 16 stasiun penelitian sangat rendah jika dibandingkan dengan hasil penelitian sebelumnya. Supono et al. (2014) melaporkan dari 36 stasiun penelitian di lokasi paling utara (Batu Kapal) hingga paling selatan (Pulau Dua) diperoleh 76 jenis ekhinodermata yang sudah berhasil diidentifikasi. Data ini lebih tinggi jika dibandingkan jenis ekhinodermata yang ditemukan di Teluk Chiriqui, Panama sekitar 17 jenis yang terdiri dari 6 jenis Asteroidea, 6 jenis Echinoidea, dan 5 jenis Holothuroidea (Alvarado et al., 2012; Guzman et al., 2004)).

\section{Indek Keanekaragaman, Kekayaan dan Kemerataan Jenis}

Hasil analisa terhadap tingkat keanekaragaman jenis ekhinodermata menunjukkan bahwa tingkat keanekaragaman di 16 lokasi penelitian berkisar 0 hingga 1,83. Lokasi dengan tingkat keanekaragaman terendah adalah stasiun 13 (Tabel 3). Di lokasi ini hanya ditemukan 1 jenis ekhinodemata yaitu Linckia laevigata. Jenis ini hampir ditemukan di seluruh lokasi dengan jumlah yang cukup dominan. Bintang laut $L$. laevigata merupakan jenis ekhinodermata umum yang dapat dijumpai pada berbagai jenis habitat mulai dari padang lamun, karang, rataan pasir yang terdiri dari campuran patahan karang, lumpur dan pasir (Laxton 1974). Ukuran tubuh (diameter dan panjang lengan) dari bintang laut ini memiliki ukuran dalam kisaran yang sama di berbagai habitat tersebut. Namun umumnya ukuran tubuh akan ditemukan lebih besar pada habitat tubir atau lokasi yang berhadapan dengan laut lepas dengan arus gelombang yang kuat. Hal ini dimungkinkan berhubungan dengan mekanisme adaptasi untuk bertahan dari kekuatan ombak.

Lokasi dengan tingkat keanekaragaman tertinggi dijumpai pada stasiun 6 yaitu 1,83. Di lokasi ini ditemukan 10 jenis ekhinodermata. Daget (1976) melaporkan bahwa jika nilai $H^{\prime}$ antara 1,0 - 2,0 maka nilai keanekaragaman jenis di suatu wilayah perairan termasuk dalam kategori sedang dan jika nilainya kurang dari 1,0 maka nilai keanekaragaman jenisnya rendah. Secara keseluruhan, tingkat keanekaragaman ekhinodermata dilokasi penelitian ini dikategorikan rendah sampai sedang. Stasiun 6 juga merupakan lokasi yang memiliki indek kekayaan jenis tertinggi yaitu 2,53. Sedangkan analisa terhadap indek kemerataan jenis menunjukkan bahwa distribusi ekhinodermata di 16 lokasi penelitian temasuk dalam kategori merata dimana indek keanekaragamannya berkisar antara 0,56-0,95. Sedangkan lokasi yang memiliki indek dibawah 0,5 hanya dua lokasi yaitu stasiun $7(0,47)$ dan 13 (0) (Tabel 2). Sebaran fauna seimbang atau merata apabila mempunyai nilai indeks kemerataan jenis yang berkisar antara 0,6 - 0,8 (Odum, 1963).

\section{Indek Persamaan}

Komposisi jenis ekhinodermata secara keseluruhan per stasiun beragam baik dari jumlah jenis maupun jumlah individu yang ditemukan. Tingkat kemiripan diatas $80 \%$ ditemukan pada antara stasiun 10 dan 15, 4 
dan 7, 12 dan 6. Stasiun 10 dan 15 memiliki tingkat kemiripan 100\% karena ditemukan 3 jenis ekhinodermata yang sama di kedua lokasi. Sedangkan stasiun lainnya memiliki tingkat kemiripan dibawah $70 \%$. Analisa terhadap jumlah spesies kumulatif yang menunjukkan jumlah maksimum ekhinodermata yang ditemukan di 16 stasiun menunjukkan bahwa jumlah maksimum yaitu 19 jenis ekhinodermata dicapai pada stasiun 8 (Gambar 6).

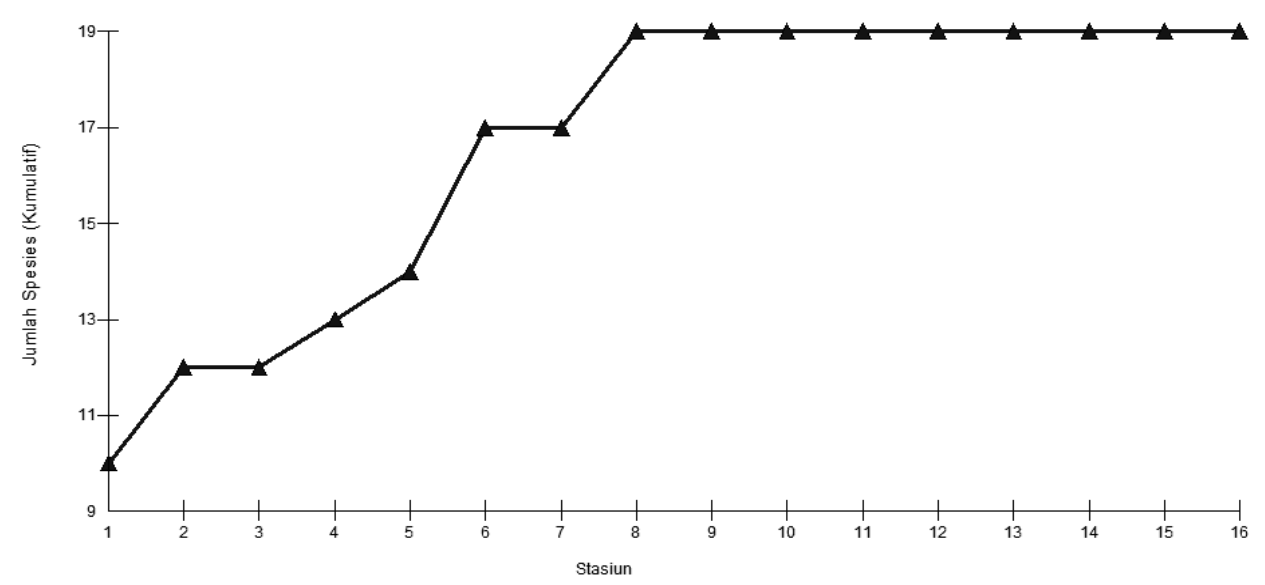

Gambar 6. Dendogram jumlah spesies kumulatif

Jumlah jenis tertinggi dicapai pada stasiun pertama dengan 10 jenis ekhinodermata, kemudian jumlah jenis kumulatif mengalami peningkatan secara gradual dari stasiun 3 hingga stasiun 8 dimana pada akhirnya mencapai jumlah kumulatif maksimum. Sedangkan jenis ekhinodermata yang ditemukan pada stasiun 9 hingga stasiun 16 adalah jenis-jenis yang sudah ditemukan di stasiun-stasiun sebelumnya. Hal ini menunjukkan bahwa tingkat kestabilan dari segi jumlah kumulatif jenis diperairan Selat Lembeh dicapai pada stasiun 8.

\section{KESIMPULAN}

Tingkat kedalaman yang memiliki jumlah jenis ekhinodermata paling tinggi adalah kedalaman $6 \mathrm{~m}$ hingga $9 \mathrm{~m}$ dan populasi ekhinodermata parasit di perairan Selat Lembeh sangat rendah (tidak ditemukan sama sekali). Hal ini menunjukkan bahwa dampak negatif dari ekhinodermata parasit terhadap kerusakan terumbu karang di beberapa lokasi penelitian sangat rendah.

\section{UCAPAN TERIMA KASIH}

Ucapan terima kasih penulis sampaikan kepada Bapak Ir. Jemmy Souhoka dari Kelompok Penelitian Konservasi Biota Laut P2O-LIPI selaku koordinator kegiatan penelitian di Selat Lembeh ini. Penulis juga menyampaikan terima kasih kepada rekan-rekan peneliti dan teknisi atas bantuannya selama kegiatan di lapangan dan selama analisis data di laboratorium. 


\section{DAFTAR PUSTAKA}

Al Hakim, I. 1983. Acanthaster planci (L.) dan peranannya dalam ekosistem terumbu karang. Skripsi Sarjana Muda, UNAS: 43 pp.

Alvarado, J. J., Guzman, H. M., and Breedy, O. 2012. Distribution and diversity of echinoderm (Asteroidea, Echinoidea, Holothuroidea) in the Islands of the Gulf of Chiriqui, Panama. Revista de Biologia Marina y Oceanografia. 47(1): 13-22.

Aziz, A. 1995. Beberapa catatan bintang mengular (Ophiuroidea) sebagai biota bentik. Oseana 16:13-22.

Baird. A.H., Pratchett. M. S., Hoey. A.S., Herdiana. Y., and Campbell S.J. 2013. Acanthaster plancii is a major cause of coral mortality in Indonesia. Coral Reefs. 32: 803-812.

Birkeland, C. 1989. The Faustian Straits of the crown-of-thorns starfish. American Scientist 77: 154-163.

Brower, J.E. and J.H. Zar. 1977. Field and Laboratory Methods for Genusl Ecology. 2nd edition. Wm.C. Brown Publishers. Dubuque, IA.

Clark, A.M and F.W.E Rowe. 1971. Monograph of Shallow-Water Indo West Pasific Echinoderms. Trustees of the British Museum (Natural History Museum), London: 238 pp.

Daget, J. 1976. Les Modeles Mathematiques en Ecologie. Masson, Coll. Ecol. No. 8, Paris: 172 pp.

De Brauwer, M., Harvey, Euan.S., Mcllwain, Jennifer. L., Hobbs, JeanPaul. A., Jompa, J., and Burton, M. 2017. The conomic contribution of the muck dive industry to tourism in Southeast Asia. Marine Policy, 83: 92-99.

De Vantier, L and Turak, E. 2004. Managing marine tourism in Bunaken National Park and adjacent waters, North Sulawesi, Indonesia.Technical Report, NRM III. Jakarta.

Eleftheriou, A and A. Mcintyre. 2005. Methods for the Study of Marine Benthos. $3^{\text {rd }}$ Edition. Blackwell Science, Oxford. 409p.

Estradivari, M. Syahrir, N. Susilo, S. Yusri dan S. Timotius. 2007. Terumbu karang Jakarta: Pengamatan jangka panjang terumbu karang Kepulauan Seribu (2004-2005). Yayasan TERANGI, Jakarta: 87 hal. 
Guzman, H. M., Guevara, C.A., and Breedy O. 2004. Distribution diversity and conservation of coral reefs and coral communities in the largest marine protected area of Pasific Panama (Coiba Island). Environmental Conservation. 31(2): 111-121.

Laxton,J. H. 1974. A preliminary study of the biology and ecology of the blue starfish Linckia laevigata (L.) on the Australian Great Barrier Reef and an interpretation of its role in the coral reef ecosystems. Biol. J. Linn. Soc., 6: 47-64.

Mcaleece, N., J. D. G. Gage., P. J. D. Lambshead and G. L. J Patterson. 1997. Biodiversity professional statistics analysis software. The Natural History Museum and The Scottish Association for Marine Science.

Moriarty, D.J.W., C. Pollard, W.G. Hunt, C. Moriarty and T. Wassenberg, 1985. Productivity of bacteria and microalgae and the effect of grazing by holothurians in sediment on coral reef flat. Marine Biology 85: 293-300.

Odum, E.P. 1963. Ecology. The University of Georgia, USA: 152 pp.

Paine, R. T., and Vadas, R. L. (1969). Calorific values of benthic marine algae and their postulated relation to invertebrate food preference. Marine Biology, 4(2), 79-86. doi:10.1007/bf00347036.

Plass-Johnson. J. G., Schwieder. H., Heiden. J., Weiand. L., Wild. C., Jompa. J., Ferse. S. C.A., and Teichberg. M. 2015. A recent outbreak of crown-of-thorns starfish (Acanthaster planci) in the Spermonde Archipelago, Indonesia. Regional Environmental Change 15(6): 1157-1162.

Supono, D.J.W Lane and Susetiono. 2014. Echinoderm fauna of Lembeh Strait. Marine Research of Indonesia Journal, 39(2): 51-61.

The Nature Conservancy. 2004. The diadema workshop. The Nature Conservancy, National Fish and Wildlife Foundation and Rosenstiel School of Marine and Atmospheric Science. 29 pp. 